\title{
Revisiting Historical Justifications of the Recall Procedures of Elected Representatives
}

\author{
Francesco CAMPODONICO*
}

\begin{abstract}
This paper shows, using a history based methodology, the differences between the "people's initiative procedures" or "progressive model" and the "authoritative body-initiative procedures" or "plebiscitary model" two structural models for recall procedure. These two heuristic models will be inferred, respectively, by the recall procedures adopted in the U.S., starting from 1903, and the recall procedures adopted in some States of Europe, starting from the Weimar constitution of 1919. The political-constitutional reasons behind the evident structural differences ("bottom-up" and "top-down" procedures) will be explained by providing an historical reconstruction about the genesis of the idea of "the recall" in the first American constitutionalism (the "Antifederalist recall"). Then the political idea behind the "progressive model" will be considered with special attention paid to the Swiss direct democracy influence on the development of the American socialists idea of the recall. The other model will be contextualized by focusing on the constitutional debate of the Germany around the late $19^{\text {th }}$ and the early $20^{\text {th }}$ century. The abuse of both procedures will be presented in two recent cases of tested recall procedures, California and Romania. Both leaded to similar results. The importance both in understanding the reference model and in providing detailed and strictly juridical regulations is highlighted to avoid the risk of abuses of these procedures by the concrete political actors.
\end{abstract}

Keywords: recall procedures, Swiss direct democracy, Abberufungsrecht, participative democracy, direct democracy

\section{INTRODUCTION}

The recent enactment of the Recall of MPs Act in the United Kingdom ${ }^{1}$ provides a good opportunity to revisit an old theme of the public law - the recall of the elected officials. The people's power to revoke the electoral mandate of their representatives has always been a sensitive topic for the doctrine, because this power emphasises the relationship between the elected representatives and the people. Moreover, it calls into question the more traditional (and political) assumptions about the representative government in modern democracies. $^{2}$

Ernst-Wolfgang Böckenförde, one of the greatest thinkers about the concept of "representative democracy", was perfectly aware of the importance of the theme and included the "recall of the elected representatives" as one of the three elements allowing the construction of a "democratic organization of the power", presenting the recall as a means "to correct and to balance democratically the (...) representative power". 3

* PhD candidate at the University of Genova. E-mail: fra.campodonico@gmail.com

${ }^{1}$ Recall of MPs Act 2015 of $26^{\text {th }}$ of March 2015, entitled "An act to make provision about the recall of member of the House of Commons; and for connected purpose", see at link 1. See Kelly, Coleman, Johnson (2010) 1-22 and Judge (2012) 732-51, Plotke (1997) 19-34.

2 More on this concept see the classic volume of Leibholz (1973). See also the important contribution of Böckenförde (2014) 2-17. For other essays on the wide theme of democratic representation in modern States, e.g., Pitkin (1967) and Urbinati (2006).

3 See Böckenförde (2014) 3. 
It is useful to investigate deeply these legal devices; understanding their working and to collect differences and analogies between the previous and currently existing recall procedures. At the end, maybe, we will be able to answer if they really are instrument capable "to balance democratically the representative power".

The well-known debate concerning the true meaning of political representation is historic. On one hand, there is Rousseau's concept of direct democracy that the people cannot be represented, as explained in his famous book Le Contrat social from 1762, and on the other, there is the idea of Emmanuel Joseph Sieyès, the great ideologist of the French revolution and writer of the famous pamphlet "Qu'est-ce que le Tiers état?". Sieyès theorized the existence of the "Nation" as a specific entity that is higher and stronger than the individuals. The "Nation" could only be represented by the members of the National Assembly. Sieyès writes: “(...) les Représentans forment toute l'Assemblée Nationale; ils en ont tous les pouvoirs. Puisqu'ils sont les seuls (highlight in the original) dépositaires de la volonté générale, ils n'ont pas besoin de consulter leur Commettans sur une dissention qui n'existe pas". ${ }^{4}$ Sieyès' dogmatic view evolved within the modern concept of "representative government" and defeated Rousseau's ideals of a direct-democracy by the people. ${ }^{5}$

However, when the first recall procedure took place in Los Angeles, in 1903, it was a turning point that recognized the people as the "source of sovereignty" and empowering the electorate with an instrument for the revocability of the public functionaries. ${ }^{6}$

Sixteen years later, in Germany, the new federal constitution (the "Weimar constitution") provided another interesting procedure that allowed the "recall" of the Reichspräsident through a popular vote (popular referendum). According to that constitution, the German president, for the first time in Europe, was elected directly by the citizens and could also be dismissed by them.

Consequently, the first, fundamental, question is "are these two procedures linked to the same Rousseauian model of "direct democracy" or are they historical examples of completely different political ideals?"

There are important procedural differences in both cases that will have to be considered notwithstanding the people's vote, a common element in both procedures. As Böckenförde stated, the "common will" of the people does not exist until it is summoned; the management of the procedure and the practical arrangements play a key role in the process of determination of this "common will".

${ }^{4}$ See Sierès (1789) 154.

5 As already affirmed by Carl Schmitt "le plébiscite de tous le jours" is not a form of State. More recently, Böckenförde (2014) 3. demonstrated that the idea to realise a "direct-identity" democracy is both practically and theoretically impossible, because a "common will" of the people does not exist at all, rather set of individual wills are given.

${ }^{6}$ See Zimmerman (2013); Cronin (1989); Crouch (1964) 10-1.; Persily (1997) 11-41.; Mack (1988) 617-40. It is interesting to see how Böckenförde, despite being very sceptical about the theorization of a "true direct democracy", recognizes the "recall of the representatives" as one of the three necessary elements (bottom-up legitimation of power, limited legal prerogatives of the representatives and recall) allowing a "democratic organization of the State power" (see Böckenförde (2014) 7.

7 "Its (of the popular will) effective development depends by someone asking: the management and the modalities of its concrete enforcement are determined by who asks the question and how it is asked, in one word: we have to interrogate it." See Böckenförde (2014) 5. 
These cases have an impact on modern day proceedings and these procedures have been tested recently, in the U.S, a famous example is the recalled California governor, Grey Davis, in 2003 and in Europe, in 2007 and 2012 against the Romania president, Traian Băsescu. Both have shown different kinds of political and juridical weakness.

Moreover, the author is convinced that the development of different models can be appreciated only in a strong historical and comparative perspective, looking for the genesis and development of different ideological justifications for recall procedures.

\subsection{The value of history in a comparative research: questions of methodology}

More than other juridical disciplines, comparative law needs a rigid criteria in developing its research, because, without a well-justified methodology could result in a mere "cherry picking activity" with the arbitrarily choice of objects of interest and ignoring other elements. Comparative activity has to find some reasons or justifications ${ }^{8}$ for the adoption of certain legal institutes in a given time and place or to find reasons for the phenomenon of "legal transplants" or, as it seems preferable, the "circulation of models". ${ }^{10}$ In the accomplishment of this task, the comparative law can be appreciated as a "science of demystification" or a "school of the truth" (école de vérité). ${ }^{11}$

Very briefly, the legal models can be understood as sets of constant elements detectable in different legal systems e.g., structural or procedural elements, identical or analogue words, terms or expressions used by the source of laws, and in different times. Obviously, this "circulating phenomenon" of the models has to be historically based by verifying the existence of coherent "legal formants" (legislative, doctrinal or jurisprudential). ${ }^{12}$ However, according to a recent development of the classical doctrine of legal formants, other elements have to be considered, such as the political and cultural ones ${ }^{13}$ i.e., the role played by political ideologies in the reception of one or another model. Without such a consideration of the political backgrounds, all comparative analysis risks being incomplete, meaningless or casual. ${ }^{14}$

Turning to the topic of this article, the primary focus switches on that "first recall procedure" (Los Angeles, 1903) rapidly duplicated by the legislation of other cities in California and, after a few years, by the constitutions of several States. A legal historical

${ }^{8}$ For this value of comparative law see Legrand (1999) 36. Especially, where the author says: "the comparison (...) search to enlighten the differences between the laws and to justify the differences".

${ }^{9}$ For this concept see the classical study of Watson (1974).

${ }_{10}$ Quite recently, referred to this phenomenon, see Cassese (2000) 65.

11 See Monateri (2012) 7 and 22.

12 As one of the most fundamental contributions to the comparative law studies, the doctrine of the "legal formants" is theorized and developed by an Italian author. See Sacco (1991) 1-2, 1-34 and $343-401$.

13 Legrand (1999) 9., refers to the "cultural context" as an unavoidable element of the comparative analysis. For the importance of "political data" even for the juridical studies, see the works of M. Weber. See also Bognetti (1994).

14 For this approach to comparative law see Bognetti (1994). 
approach will show if and how it is possible to find a common procedural structure for all the numerous recall procedures adopted in the U.S. For several reasons, this common structure will be the "people's initiative procedure" or "progressive model".

Analogously, the article 43 of the Weimar constitution ${ }^{15}$ will be considered in order to understand the evolution of a different model for recall procedures: the "authoritative bodyinitiative procedure" or "plebiscitary model". As will be explained later in the article, the plebiscitary model entered in other constitutions of European countries including Austria, ${ }^{16}$ Romania, ${ }^{17}$ Iceland, ${ }^{18}$ Slovak Republic, ${ }^{19}$ and, with some differences, in Latvia. ${ }^{20}$

\subsection{Recall or recall procedure? A terminological issue}

The term "recall" is vague within the U.S. context because a unique (a federal) legal institute called "recall" does not yet exist. ${ }^{21}$ There are, however, a multitude of different recall procedures, provided by the laws or by the constitutions of several states and cities of the U.S. ${ }^{22}$ Every procedure differs in terms of requisites for the proposition of the recall petitions; the respect of vacation terms; the different amounts of signatures required, the passive subjects of the procedure (only the elected functionary or even the appointed functionary?). Nevertheless, it can be seen that there are some constant structural elements, starting from the central role of the people, those who hold the petition initiative and the possibility to call for a recall election.

In the same way in the "plebiscitary model", the people are involved in the procedure and they have to decide whether to confirm the President or the members of the Parliament.

Considering these analogies, it seems that the term "recall" can be used only in a general sense, as a synonym of "revocation by popular vote". In this way, it refers not to the entire phenomenon of the revocability of public officers but only to those revoking procedures involving the vote of electorate.

15 For an English translation of the text of the Weimar constitution, see at link 2.

16 Art. 60, par. 6, Const. (1920, after the 1929 revision).

17 Art. 95, Const. (1991).

18 Art. 11, par. 3 and 4 Const. (1947).

19 Art. 106 Const. (1992).

20 Art. 48 and 50 Const. (1922, after the 1999 revision).

21 The Supreme Court of the U.S. did not allow recall procedures against the members of the Congress, declaring unconstitutional all the attempts made by the State to introduce such procedures. See, e.g., U.S. Term Limits, Inc. v. Thornton. No. 931456. Supreme Ct. of the US. 22 May 2005. For an analysis of the doctrine see: Zick (1999) 572-611.

22 For a calculation of the number of the U.S. states that "authorize the recall" see Zimmerman (2013) 34-5.; and, for the number of the cities, see: Feeney (2007) 37-92. 
The validity of this definition appears clearer if compared with other systems for the revoking of public officers, such as the impeachment procedures, ${ }^{23}$ votes of confidence of the Parliament, ${ }^{24}$ and "trials in courts" ${ }^{25}$ against the President or the ministers of the Cabinet.

Concerning the case of impeachment, some exceptions exist despite the classical structure of procedure, "articles of impeachment" made by the lower chamber of Parliament and the right to "try all impeachments" conferred to the upper chamber. ${ }^{26}$ However, in general, the impeachment consists in a juridical/political procedure allowing the Parliament or only one chamber, to vote regarding the (political or juridical) responsibility of determined public functionaries and, in case, to remove them from their office. Clearly, in these cases, the people's vote does not intervene until the end of the whole procedure.

In the other two scenarios, votes of confidence and juridical trials, public officers are judged and may be removed from their charge by the means of a parliamentary vote or, in the second case, by the ruling of a Court. There is no people's intervention during all the revoking procedure.

Moreover, the word "recall" can be used to indicate a specific procedure if the state's legislation or constitution refers to it by name e.g., "the recall in California" meaning the recall procedure provided by the article $2, \S 13$, and article $23, \S 1$, of that Constitution. ${ }^{27}$

Nevertheless, a century ago, the term "recall" was used in common speech with an assumed vague meaning of a juridical/political device to remove a public officer e.g., a governor, a deputy, a mayor. Consequently, the term "recall" started to be intended, even by many authors in doctrine, as a general and unspecified legal institute, identifiable, each time, by referring to said events like the Recall in Oregon and the Californian Recall. ${ }^{28}$

23 The impeachment began in England in the late fourteenth century, allowing the Parliament to pursue for "treason", "felony" and "high crimes or other misdemeanours" any person, but mostly the king's counsellors (or ministers). After the indipendence and with the new federal constitution, the impeachment procedure was receipt even in the U.S. where it is used to judge a series of (political/ juridical) crimes committed by high federal officers (included the president). On the history of impeachment see, ex multiis, Berger (1973) and Oliviero (2001).

${ }^{24}$ In the English constitutional system the lack of confidence between the Parliament and the Government replaced the impeachment procedures. These are now outdated. However, in many parliamentary and semi-presidential systems the confidence vote is a political and "easy" instrument to remove the PM or the ministers. For examples, in Italy, the Constitutional Court recognized (see ruling $\mathrm{n} .7$ of 1996) the constitutional legitimacy of a parliamentary motion of lack of confidence against a single minister.

25 "Trials in courts" is used to underline the difference with the classical impeachment procedure, which is a completely political-managed procedure. Here reference are made to those cases in which the president or the ministers are judged for their crimes (common or political) by the courts (such as the Constitutional Court, the Supreme Court or Court ad hoc) and not by the Parliament. For example, the Italian case where the President is impeached by the Parliament but they are judged by the Constitutional Court (art. 72 Const.). See analogue "trial court" procedures adopted, e.g., in Austria (art. 142), Germany (art. 61), and Poland (art. 145).

26 The French system is one such example but there are numerous cases. According to the constitution, the President of the Republic is subject to a parliamentary trial, the jury is the entire Parliament, with both the Assemblée Nationale and the Sénat, after a qualified majority vote by the two chambers separately.

27 For a first use of the term "recall" in this specific sense see: Bird (1930).

28 See, e.g. Barnett (1915). 


\section{REVISING THE ORIGIN OF THE RECALL PROCEDURES IN THE UNITED STATES OF AMERICA}

\subsection{The Articles of Confederation and the Antifederalists' recall}

Several scholars are used to think of recall as a legal institution deeply rooted in American history ${ }^{29}$. But recall only appeared in the 5th article of the Articles of Confederation $(1777)^{30}$, allowing the member States to "recall" their delegates. Nevertheless, the Articles did not specify the procedure to follow and each State could independently determine the procedure, with an ad hoc statute or by approving an amendment to the constitution. Unfortunately, the States did not develop that procedure and none of the delegate was recalled during the few years of the American Confederation. ${ }^{31}$

However, the recall was completely absent in the new federal Constitution text of 1789. The reason for this disappearance can be found in the political orientation of the recall supporters; they were antifederalist partisans ${ }^{32}$ and wanted to use this tool as a means of disempowerment the new Federal Congress, keeping the elected "under control" of the States. ${ }^{33}$ However, the Federalists stated the recall was useless because it was never used during the Confederation. The Anti-federalists said that it worked "without noise"; delegates fearing to be recalled, respected their mandate (a "sword of Damocles"). In the antifederalist delegates' vision the recall provided in 1777 was successful and had to be conserved. ${ }^{34}$

A draft of the new constitution, the Virginia Plan, presented by Edmund Randolph proposed to introduce the "recall" against the members of the "first branch of the National Legislature". However, it was rejected. ${ }^{35}$

${ }^{29}$ Being linked with the American direct democracy traditions. For example, Elizabeth E. Mack recalled the usage of the "town meetings" by the Early Americans colonials. These meetings were comprised of all the town men who dealt with issues by consensus. Today similar meetings are held in some cities of New Hampshire and Maine. It is also interesting to observe that in Europe the "town meetings" were born in Switzerland.

${ }^{30}$ Article V: "For the more convenient management of the general interests of the united states, delegates shall be annually appointed in such manner as the legislature of each state shall direct, to meet in Congress on the first Monday in November, in every year, with a power reserved to each State to recall its delegates, or any of them, at any time within the year, and to send others in their stead for the remainder of the year". See the original text of the Articles at link 3.

31 See on this De Franciscis (2007) 19-42.

32 Among the others, it is possible to recall here the names of Patrick Henry, Gilbert Livingston, John Lansig and the so called "Federal Farmer" (maybe - but there is still a debate between historians - Richard Henry Lee). See Antifederalist Paper n. 53, entitled A Plea For the Right of Recall and signed by Amicus (Patrick Henry). The article was published on Columbian Herald, 28 august 1788 (now collected in Borden (1965) 47).

33 For this approach to the theme of recall see The Federal Farmer, Letter XI. January 10, 1788 in Storing (1981) 286-9.

34 See Elliot (1827) 294.

35 Originally the project was elaborated by Alexander Hamilton. For the text see Elliot (1827) V. 
The Antifederalists ${ }^{36}$ carried on their battle for the recall in the different States during the Special Conventions held for the ratification (and amendment) of the constitution. ${ }^{37}$ All their proposals and attempts to introduce a recall procedure failed. The three famous authors of the Federalist Papers, Hamilton, Madison and Jay (they signed their articles as Publius) were fiercely adverse to the recall of elected representatives as they considered it as a destabilizing legal institution. They refused the "democratic government" of the people and worked for a "republican government", 38 in which the decisions would have to be taken by the elected and not the electors. Above of all, a government of the "masses" was feared and also the political populism, viewed "implicit", in allowing any kind of recall procedure. On the other hand, they intended to protect the people from "bad representatives" by different constitutional means like "frequent elections", according to the Constitution of 1789, the House of Representatives was completely re-elected each two years. Publius also rebuffed the idea of recalling senators, elected for a long-term mandate - six years, because the Upper House had to serve as a balancing power against the populist tendencies in the Lower House. ${ }^{39}$

Nevertheless, one thing remained certain: the fear of the Framers of the absolute power. This fear was quite understandably inherited from the Pilgrim Fathers, who suffered political persecutions in Europe. According to several authors, both the recall and the impeachment were a sign of the will to maintain the elected representatives and the Executive inside the limits of the laws. This was limited to a few people; a chosen political élite (for Madison), ${ }^{40}$ and not the masses as it could lead to a "mass anarchy".

The lack of sympathy for direct democracy, showed by many Framers, can be attributed with the role that Calvinistic ethic played. A doctrine stated that "(I)f the Framers were operating at least in part from the Protestant notion of calling, then direct democracy would seem problematic when it requires the individual citizen (rather than the representative) to become an expert on a wide range of issues. State initiatives and referenda capable of covering broad areas of policy are in conflict with this understanding of the role of the person in society." 41

However, after the constitution was ratified, the "issue of the recall" seemed to disappear from the public debate in the U.S. It would be back only one hundred years late (but it would be completely different).

36 But not all of them. "[M]any Antifederalists" Zick explains "believed that the frailties and passions of ordinary men made them incapable of responsible participation in government. Still, there were those Antifederalists who viewed a form of explicit representative democracy as vital." see Zick (1999) 572.

37 See, e.g. the Gilbert Livingston's amendment at the New York Special Convention, as reported in Borden (1965) 152.

38 As very well said, more recently, by Merci Hamilton: "The republicanism crafted by the Framers works in significant part because each entity - individual citizens, the people as a whole, representatives, branches of the government, and the state and federal governments - is checked in some meaningful way to steer it away from tyranny and toward the common good." See Hamilton (2004) 411-56.

39 See the Federalist papers n. 57 and 63, they are available even on line at link 4.

${ }^{40} \mathrm{He}$ wrote in the Federalist n. 10 the public views would be "refine[d] and enlarge[d]" by "passing them through the medium of a chosen body of citizens". Hamilton recommended that "the national legislature should be composed only of landholders, merchants, and men of the learned professions." the Federalist No. 35. See more on Zick (1999) 572.

${ }^{41}$ Hamilton (2004). 


\subsection{The amendment to the City Charter of Los Angeles in 1903 and the political backgrounds.}

According to recent studies, ${ }^{42}$ the debate around the introduction of recall procedures restarted at the end of XIX century and many American scholars of that period proved to be interested in. ${ }^{43}$ Finally, in 1903, the first recall procedure was introduced in the City Charter of Los Angeles ${ }^{44}$, following the amendment-process started three years before. ${ }^{45}$ For the first time in the U.S. history, this new procedure allowed the electors to remove "any incumbent of an elective office, whether elected by vote of the people or appointed to fill a vacancy". Shortly, a petition signed by the $20 \%$ of the "entire vote cast for all candidates for the office, the incumbent of which is sought to be removed" was required to start the recall procedure. A "recall election" was supposed to be held in short time after fixed amount of signatures was reached and the people would have to choose if they want to conserve the officer or wanted change.

In 1908, Oregon was the first state to adopt a recall procedure in its constitution. ${ }^{46}$ After that the recall procedures diffused widely across the U.S. and, now, there are sixteen states providing with this legal instrument in their constitutions. ${ }^{47}$ Today the amount of the "objective" 48 and "subjective requisites" 49 for the proposition of a recall petition differs from state to state and city to city.

With respect to the "objective requisites", it is possible to distinguish between states (and cities) in which the petitions have to specify the juridical reasons for the recall of an elected officer (called "judicial process") 50 and others in which it is not required. In these latter cases, a general declaration of "lack of confidence" of the electorate against the officers subjected to the procedure is generally sufficient ("political process"). ${ }^{51}$

In some cases, a maximum term has to be respected for the collection of the signatures or, a limit date for the circulation of the petitions or modules. ${ }^{52}$ In several cases it is also

42 See Ronchi (2009) 99-129; Bird, Ryan (1930) 32ss.

43 A first example in Sullivan (1892) 39. Here the Author quotes also the usage of the Abberufungsrecht in Switzerland.

${ }^{44}$ See the text of the "section 198-p" of the City Charter (see at link 5). On this amendment see also: Shaffner (1915) 37; Phelps (1915) 1; Munro (1912) 42; Crouch (1964) 10.

45 The Board of Freeholders (composed by fifteen members and chaired by the progressive leader John R. Haynes) was the special commission charged to do the reviews and it held its first meeting the 17 july 1900. On this Bird, Ryan (1930) 32.

46 Article 2, Section 18, of the Oregon constitution. See Barnett (1915) 189 and Feeney (2007) 40 .

47 The state constitutions that allow a recall procedure are: Alaska (art. 11, §8), Arizona (art. 8, $\S \S 1-6$ ), California (art. 2, $\S 13$ e art. 23, §1), Colorado (art. 21, §1), Idaho (art. 6, §6), Kansas (art. 4, $\S \S 3-5$ ), Louisiana (art. 10, §26), Michigan (art. 2, §8), Minnesota (art. VIII, §6), Nevada (art. 2, §9), New Jersey [art. 1, 2(b)], New Mexico (art. 10, §1), North Dakota (art. 3, §§1 e 10), Oregon (art. 2, $\S 18$ ), Washington (art. 1, §§33-34), Winsconsin (art. 13, §12).

48 E.g., the format for the circulation of the recall petitions, the number of the signatures required, and the structural or functional quorum for the recall elections.

49 See supra at II, section 2.

50 The States requiring "specific grounds" for the presentation of a recall petition are: Alaska, Georgia, Kansas, Minnesota, Montana, Rhode Island, Virginia e Washington. See Zimmerman (2013) 15.

51 On this see Zimmerman (2013) 43.

52 The term is variable: from the 180 days of Louisiana to the 60 days of Colorado. 
mandatory to consider a vacation term from the beginning or the end of the mandate of the public officer. Differences exist in the number of signatures required to support the petitions. ${ }^{53}$

Indeed, the recall elections of public functionaries can be distinguished by the modalities in which the substitution of the officer concerned can happen by:

a) a simple vote to revoke the mandate of an elected ${ }^{54}$

b) a double vote, one removing the subject and the other choosing the substitute ${ }^{55}$

c) an open campaign, similar to an English by-election in which all the subjects, including the recalled officer can participate..$^{56}$

However, there are important fixed elements or structural constants between these procedures. All of them preview the instrument of petitions as the only way to start the procedure. These petitions have to be signed by a certain number of registered electors of the state or city. There is no means in which the legislative or executive powers could interfere with these procedures or stop them. A complete inversion in the procedural structure never happens - no constitution or city charter can confer the recall initiative to a different organ of the state as an "authoritative body" e.g., the parliament of the state or the government. ${ }^{57}$ In all cases, the electorate remains the starting point of the entire procedure.

However, this is extremely interesting because it is narrowly linked with the political/ ideological background of the first U.S. recall procedures and it is interesting to see who supported/fought for the introduction of recall procedure in the U.S. legal system.

There were the Socialist Parties of America, initially the Social Democratic Party of America and, then the Socialist Party of America, ${ }^{58}$ whose members are mainly of German origins (an important point for later consideration). These two left parties proposed the introduction of the "binding mandate" for all public officers together with the referendum and popular initiative ${ }^{59}$ then accepted usages of "recall" following the "American style" or as a means to increase their political propaganda.

On the other hand, there were the "Progressive movements", a populist movement that developed in the first years of the 20th century, the "Progressive Era" ${ }^{60}$ Their anti-

53 There are four criteria of classification, see The Book of States 1996-7. Lexington, 1997, $221-2$.

54 See art. X (26) of the Louisiana constitution.

55 As happened in California, when the governor Gray Davis was recalled in 2003.

56 See art. VIII/I (4) of the Arizona constitution. More recently, this solution is adopted by the U.K. in the Recall of MPs Act of 2015.

57 For a structural difference between «full recall» and «mixed recall» procedures, see the chapter 5 of Direct Democracy: The International IDEA Handbook 2008, International Institute for Democracy and Electoral Assistance (IDEA), available at link 6.

58 See the Platform of the Social Democratic Party of America adopted in Chicago, June 21, 1897, now collected in Heath (1900). At the point 8 of the Platform the socialist leaders have already made a claim for " $(\mathrm{t})$ he adoption of the Initiative and the Referendum, the Imperative Mandate and Proportional Representation". Few years later, in 1901, the Socialist Party of America was the first Party to introduce in its Manifesto an explicit reference to "the recall", see the text of the Political Manifesto in Social Democratic Herald, v. 4, no. 7, Milwaukee, 1901, n. 159, 2-3.

59 It seems noteworthy the fact that the first referendum and initiative procedures were introduced in South Dakota in 1898, see Persily (1997) 16.

${ }^{60}$ Mack (1988) 621. In general, on the "Progressive movement" see: Holligsworth (1912) $32-48$. 
establishment propaganda became strong in California, due to the political scandals involving the economic relations of the two traditional parties with a powerful private company, the Southern Pacific Railroad. ${ }^{61}$ Here, John R. Haynes, ${ }^{62}$ chief of the "Direct Legislation League" of California, successfully led the battle for the introduction of the "plebiscitary trinity" (referendum, initiative and recall) and found more popular consensus. Haynes saw the liberation from the railroad trusts in the direct democracy "which dominated the State politics" and, the possibility to realize the "government of, by and for the people". ${ }^{63}$

Through massive propaganda in local newspapers ${ }^{64}$ and heavy rhetorical and demagogic speeches, like "How best can we arm the People to protect themselves hereafter?", Haynes reached the chair of the Board of Freeholders and was charged to make the amendments to the City Charter. The State Senate stopped the first attempt but these amendments were after ratified by the popular vote, following a special referendum process, introduced in 1902.

At this point, it seems quite clear that the political ideology driving the first introduction of recall in the "modern" U.S. was completely opposite from the old "Antifederalist recall".

\subsection{Looking for the origin of the socialist idea of the recall of public officers}

The socialists also have fought for the recall, as a means to introduce the "binding mandate" in America. However, they did not share the same "populist trends" of the Progressives but fought for a device they believed would be the end of the bourgeois government. In order to understand the gravitas of this point, a brief review of the socialist thought about the specific point of the "binding mandate" is required. This was opportunely translated, for an American "audience", as "recall".

In 1762, Jan-Jacques Rousseau theorized the existence of a people-assembled power to recall all public officers. It is a possibility that these theories were derived from the medieval experiences of direct democracy in the medieval cities of Switzerland, ${ }^{65}$ where the quite

${ }^{61}$ More details in Persily (1997) 53. See also Garrett (2004) 240: "California adopted a statewide recall procedure in 1911 as part of an effort by John R. Haynes and other progressives to implement a system in which corrupt officials at both the local and state levels, particularly those beholden to the mighty Southern Pacific Railroad, could be removed before a regularly scheduled election."

62 See Sitton (1988) 2-17. See also the contributions of Robert La Follette (e.g., see his intervention, entitled "Initiative, Referendum and Recall," in The Progressive, December 10, 1910).

${ }^{63}$ Persily (1997) 29: "In California, the legislature was controlled by the Southern Pacific Railroad and the Knights of the Royal Arch (brewers and distillers)."

64 "Aided by writers from the Los Angeles Express, one of the few newspapers not dominated by the railroads, the Progressives, through an organization they named the Lincoln-Roosevelt League, launched a methodical campaign both in the press and in the courtroom to expose corruption inherent in every railroad-dominated city government." Persily (1997) 29.

${ }^{65}$ About the sources of inspiration of Rousseau's idea of direct democracy there is a huge debate. However, important French authors have made some hypotheses about the Swiss medieval experience of the "town meetings." See on this Esmein (1896) 255; Duguit (1923) 475; and Burdeau (1932) 388 . 
obscure system of "Landesgemeinde", a form of town meeting, allowed direct popular decisions in many fields. ${ }^{66}$

There is a large volume literature concerning the direct democracy constitutional devices provided by the cantonal constitutions in Switzerland ${ }^{67}$ and, for many aspects, the Abberufungsrecht (literally: "right to recall") is relevant. ${ }^{68}$ Following the Act of Mediation of $1803,{ }^{69}$ this institute was introduced in seven constitutions and since then has been conserved until today. ${ }^{70}$ In the majority of these cases, the procedure still presents a first phase, in which the electors can collect the signatures required for the petition, and a second phase in which the people can vote on the revoke. The peculiar feature is it can be used only against the entire organ (entire cabinet or the entire legislative assembly according to the cantonal provision) - the electors cannot vote for removing only one member of those institutions.

The Abberufungsrecht has been defined a dormant institution, due to the limited use of the procedure. ${ }^{71}$ However, it is noteworthy that the U.S. doctrine, at the end of the $19^{\text {th }}$ century, was already studying these procedures at least, together with the Swiss referendum and initiative. ${ }^{72}$

The Swiss recall, however, was quite successful in Central Europe and according to Robert H. Wells, ${ }^{73}$ the Swiss precedent was source of inspiration for the recall procedures adopted in many cities and Länder in Germany, starting from the half of $19^{\text {th }}$ century. Here, the Volksbegehren (popular petition) and the Volksentscheid (popular deliberation) represented and still represent the two main phases of the recall procedures provided by the constitutions of six Länder. $^{74}$ Even in these cases, the people could collect the required

66 Some information (in English) about these ancient institution ("old folk-mote") are given by Dubuois, Fleeney (1998) 256-7. An historical reconstruction was offered, at the end of XIX century, by Vincent (1891). According to Vincent view: "This was a meeting of the inhabitants of Schwyz, for the purpose of making regulations for the sale of their common lands and for taxation" (ivi, 107). Today, Landesgemeinde still happen in two Swiss Cantons: Glarus and Appenzell Innerhoden.

${ }^{67}$ For an historical approach to the theme of referendum see Aubert (1974) 3-16.

68 For a recent and analytical essay (available in English) on the recall in Switzerland see Serdült, link 7. The A. explains the Swiss recall is considered a "measure of last resort", otherwise, in "normal" cases, the criminal courts intervene to sanction corruption or other scandals involving the elected officers. See also Church (2004) 141-6. En French language, instead, see Giraux (2013) at link 8.

69 Thought this Act Napoleon concluded the brief experience of the Helvetic Republic (1798$1803)$.

70 The Helvetic Republic was a unitary state, which comprehended 13 cantons of the previous Switzerland Confederation. The constituent assembly of Aarau promulgated its constitution the $12^{\text {th }}$ April 1798. The Cantons adopting the Abberufungrecht disposition in their statute were: Basel-Stadt, Bern, Fribourg, Zürich, Luzern, Schaffhausen and Solothurn. See on this Olivetti (2001) 355-78.

71 See Serdült link 7, 8. The only successful recall procedure in Switzerland took place in Aargau in XIX century. Moreover, after that, the Aargau recall procedure was abolished. As showed by a graph in the quoted article, Ticino still has the most attempts.

72 As proved by the amount of studies existing, e.g. Hazeltine (1907) 202-13; Rappart (1912) 110-45; Munro (1912) 4; Johnson (1912) 139-64.

${ }^{73}$ Who studied the system of the German referenda. See Wells (1929) 29-36.

74 Baden-Württenberg, Bavaria, Berlin, Brandenburg, Bremen, Rhineland-Palatinate. For further details see, e.g. Gunlicks (1998) 105-25. 
signatures and call for a popular referendum for the dissolution (revoke) of the entire legislative council or the parliament of the Land.

To show the Swiss influence on the German procedures, Wells recalls the influence of the contributions of two socialist writers, Moritz Rittinghausen and Victor Considérant. ${ }^{75}$ Considérant was influenced by Rittinghausen but they elaborated a concept of direct legislation by the people, "law making by means of referendum and popular initiative", ${ }^{76}$ as the only juridical device allowing the subversion of the bourgeois and oppressing state. Recalling Rousseau's most important assumption, Considérant wrote that "If the people delegates its sovereignty, it abdicates it". To avoid this bad outcome the people have to govern directly. How they can do it in certain terms? Here the clearest link between the direct legislation of the people and the recall procedure against the public officers can be found.

"The People vote on the principle of the laws. The votes are counted in each local section (...) and the real and direct collective will of the People or of the majority is manifest. There is now a law. It only remains to draft it. That is done by the minister appointed by the People, who will conform to the will of the people for several reasons: first because a minister naturally obeys the Sovereign on whom he depends. Second, because if the Sovereign were dissatisfied with its minister, it would dismiss him instantly. $(\ldots)^{\prime \prime} .{ }^{77}$ It is also noteworthy that Considérant spent a few years in Texas, where he unsuccessfully tried to carry on a project of Fourier's Phalanstère, a sort of workers commune based on direct democracy, and where he probably tried to share his ideas with the raising socialists forces.

In the following years, all these assumptions about the evolvement of the people in legislation became definite part of the first socialist party manifests ${ }^{78}$ and even in the famous Gotha program (1875) this statement can be found "The Socialist Labor Party of Germany demands as the foundation of the state: (...) 2. Direct legislation by the people". ${ }^{79}$ Karl Marx explicitly referred to the "right of recall of all public officers" in La guerre civile en France (1871), praising the Paris Commune experience. ${ }^{80} \mathrm{He}$ understood the "binding mandate" for all elected and unelected public officers as a legal means aiming to dismantle completely the government, which he had defined as "a committee for managing the common affairs of the whole bourgeoisie". ${ }^{81}$

Moreover, according to a Swiss scholar, Uwe Serdült, who has explored the theme, "it seems that John R. Haynes got the idea by reading a famous book of Parsons". ${ }^{82}$ In this book this Author showed how to realize his political ideals of direct democracy, wellsummarized in a rhetoric question of the introduction, "Shall the people own the city and its

75 Rittinghausen (1850); Considérant (1851).

76 See on this Bullock (1987) 62-81.

77 Considérant (1851) 19-20.

78 See Ensor (1910) 319-58.

79 For an English translation see Hamerow (1973) 230-2.

80 See the "Appel aux électores" of 22 March 1871 at link 9. In this Appel the Central Committee of the National Guard declared that: "The Member of the municipal assembly, shall be controlled, surveyed, and subjected to the public opinion; they are revocable, accountable, and responsible."

81 See the text of the Manifesto of the Communist Party at link 10.

82 See Serdült at link 7, 2. The book's reference is Parson (1901). 
government or shall they be owned by the politicians and monopolists?" and to contrast the distortions of the representative system. ${ }^{83}$

However, it is proved that, following the socialist "European" teachings, the American socialist leaders (like Alfred Berger or Eugene V. Debs) started to include "the referendum, the initiative and the recall" in their speeches between the late $19^{\text {th }}$ and early $20^{\text {th }}$ century and, the "plebiscitary trinity" in their political propaganda. ${ }^{84}$

The political fights for the (re)introduction of the "recall" in the U.S. public and scientific debate, however, brought with them a definitional/terminological "chaos". The old antifederalist concept of recall was no more applicable to the "modern" procedures and these developed so quickly and in so many different ways that it became impossible for the scholars to manage for a unifying definition.

\subsection{The "difficult" definition of "the recall" in the $20^{\text {th }}$ century U.S. doctrine}

The fast development combined with a wide diffusion of the "recall" in the U.S. resulted in scholars trying to define the phenomenon. In one of the first essays on the theme Delos F. Wilcox said that recall was "a guaranteed right of the people to discharge their public servants when these public servants cease to be satisfactory to them", ${ }^{85}$ but for many other authors it was "only" a "legal provision for the retirement of a public officer before his term of office expires, if he has forfeited the confidence of the voters". ${ }^{86}$

The analysis of these definitions ${ }^{87}$ lead to the "recall phenomenon" by the first American doctrine, in the $19^{\text {th }}$ Century, led to three critical questions:

1) Is the recall a right or a legal procedure?

2) Who are these "public servants" or "public officers"?

3) What means "cease to be satisfactory" to the people or "he has forfeited the confidence" of the voters?

The unclear definitions offered by the first doctrine generated not only terminological but also conceptual problems. For example, was the revocability of an appointed and thus non-elected official, implied in the concept of recall ${ }^{88}$ Did the voters have to allege the motivations or the facts at the basis of their request for a "recall election" in their petitions?

An answer to these ambiguities can be found in the fact that they reflect the existing differences between different recall procedures. ${ }^{89}$ The great diffusion of this legal instrument, did not allow the perpetuation of a procedural homogeneity. In this process of

83 "The problem is to keep the advantages of the representative system (...) and eliminate its evil, haste, complexity, corruption errors (...). The solution lies in a representative system guarded by constitutional provisions for popular initiative, adoption, veto and recall." See Parson (1901) 256.

${ }^{84}$ More details in Testi (1980). See, e.g., the Berger's articles on the Social Democratic Herald, in 1902 quoted in Testi (1980) 137.

85 Wilcox (1912) 169.

${ }^{86}$ See Shaffner (1915) 37.

87 See also the definition given by the National Municipal League, as reported in Farmer (1912) 60 .

88 An interesting and controversial case was about the introduction of the recall of judicial decisions. Important politicians, such as Theodore Roosevelt, supported this introduction. See Stagner (1980) 257-72.

89 Even today, some procedures admit petitions for the recall of the members of the judicial power (as in several cities of Wisconsin). Other procedures, instead, allow petitions only for the elected officials in different branches (legislative or executive). See on this Zimmerman (2013) 90. 
expansion the "original model" received modifications, adaptations and extensions or it was subjected to different interpretations, mostly given by the state courts.

More recently, some American scholars (Thomas Cronin and Joseph Zimmerman) noticed these definitional inadequacies to the complexity of the "recall phenomenon" and started to change their attitude toward the problem. For example, Thomas Cronin, around the end of the 1980s, presented the "recall" as "the procedural democracy device that allows voters to discharge and replace a public official", 90 so the "recall" was no longer "a right" but became a "procedural democracy device". ${ }^{91}$

The definition proposed by Joseph Zimmerman confirmed Cronin's conclusion and added "The recall is a participatory device allowing voters by means of petitions to place the question of removing an elected officer on the ballot before the expiration of the term of office, thereby recognizing the electorate as the fountainhead of the sovereign power". ${ }^{92}$ Even if this last definition of "recall" is not completely satisfying because it does not consider, for example, the case of unelected officers, nevertheless it underlines, for the first time, a very important element - the people as the "fountainhead of the sovereignty". This is the most important contribution given to the quest for a common structure between the U.S. recall procedures.

\subsection{From the past to the present: the "economical manipulation" of a recall procedure in the last "Californian case"}

In 2003, a recall petition against the governor Gray Davis was signed by the $12 \%$ of those who voted at the last gubernatorial elections $(897,158)^{93}$ as required by the Art. II, $\S 14$ (b) of the California Constitution, after thirty-one attempts to qualify a gubernatorial recall for the California ballot including a first attempt against Gray Davis. ${ }^{94}$ First, it is important to consider the California rules concerning the impeachment procedure allow the recall election be held together with the new election for governor. For this reason, many candidates ambitious to get the place, including also Arnold Schwarzenegger, decided to support that recall petition. As reported by scholars, the recall forces were helped in collecting all the required signatures by a substantial amount of money from private financers, especially from the Republican Darrell Issa who paid 2 million dollars to finance the recall promoters.

The key element for a winning petition circulation it is the possibility to have paid circulators. Since 1988, when the Supreme Court struck down as unconstitutional the state laws banning paid circulators, ${ }^{95}$ these types of circulators have been allowed anywhere. In the last California case, the huge amount of money ( 2 million dollars) spent by rich but not uninterested private individuals led to a collection of 1.36 million signatures. Moreover, in California a strong, professionalized initiative industry of consultants, including

90 See Cronin (1989) 125.

${ }^{91}$ However, the jurisprudence remains not unanimous. E.g., in 1915, in one of the first cases the California Court of Appeals stated the recall was not properly a right of the people but a procedure that could be construed liberally and not limited to the cases of violations of laws. More lately, in 1983, the Colorado Supreme Court declared the recall to be "a fundamental constitutional right."

92 See Zimmerman (2013) 12.

93 See all these data in Garrett (2004) 240.

94 See Garrett (2004) 240; for more details about the previous attempts see also: Bowler, Cain (2004) 7-9. On the Gray Davis' recall also Miller (2005) 135-62.

95 See Meyer v. Grant, 486 U.S. 414 (1988). 
companies "that offer clients a money-back guarantee if they do not produce enough valid signatures to qualify something for the ballot; in return, they are paid about $\$ 1.50$ per signature" $" 96$ has developed.

According to several scholars, all these elements are a clear distortion of that "progressive idea" of the recall drafters, where the more or less large amount of signatures required was a sign of the popular support for the request. This requirement should serve to guarantee both the elected officers and the electors: The officer should not have to fear a request for recall election if it is not shared by many people and the electors that they conserve power on these procedure and it cannot proceed with a their quite large consensus. Moreover, the drafters of this procedure were thinking to common work of all volunteers and surely cannot image the intervention of professionals.

Elisabeth Garrett correctly observed that the introduction of a paid system for the collection of signature "strengthens the hand of those who can afford to spend substantial money on a petition drive." Allowing rich and interested citizens to pay for a successful procedure when they know it is the right moment e.g. according to the polls a scandal, a political mistake, in the case of political weakness of the target-officer, as in the Gray Davis case.

However, after the verification of the achievement of the required signatures, the date of the recall election (and of the contextual eventual election of the new governor) was fixed. The most famous Republican candidate to the "replacement" of Davis, Arnold Schwarzenegger, spent over 10.5 million dollars of his own money on his campaign. Clearly, the financing problems connected with an electoral campaign are always a sensitive topic in the U.S., but, in the California case of 2003, they mixed with the recall procedure due to the fact that the California recall elections are held together with the eventual and consequent election of the new officer. The interesting point is that while the other candidates at the eventual substitution of Davis were bound to maximum contributions of 21,200 dollars from each individual, the candidates supported by the committee pro or against the recall did not suffer the same limitations. Actually, the contributions to the recall campaign are not bounded to a certain amount. For example, Davis collected 18.3 million dollars for his committee "Californians Against the Costly Recall of the Governor", "a sum made possible by the absence of contribution limitations". ${ }^{97}$ Schwarzenegger also used "separate pro-recall committees" to support the campaign for the recall but no one could avoid that this separate committees used the same slogans and images used by the official committee for Schwarzenegger as a candidate he was subjected as the other to the bound of money contribution so, indirectly, supporting his candidature. ${ }^{98}$

96 Garrett (2004) 241.

97 Garrett (2004) 250.

98 "Unless a viewer noticed the fine print identifying the sponsor of the ad, she would be hardpressed to tell the difference between one funded by the Schwarzenegger campaign committee and one paid for by the "Total Recall" committee." 


\section{A DIFFERENT MODEL? \\ THE PRESIDENTIAL RECALL IN THE WEIMAR CONSTITUTION: GENESIS AND DEVELOPMENT}

\subsection{The article 43, section 2, of the German Constitution of 1919 and its homologues in Europe}

After the end of the First World War and the abdication of the Kaiser Willem II, Hugo Preuß, a Berliner jurist of Jewish origins, was charged by Friedrich Ebert, the interim president of the Reich, to prepare the draft of the new constitution of the first German republic. ${ }^{99}$ For the form of government of the "New" Germany, he proposed an interesting mechanism which partially anticipated the French constitution of the Fifth Republic with a President directly elected by the people, a powerful Government and a strong Parliament, at least the Reichstag, the elective Chamber of the Parliament. ${ }^{100}$

As well as a "semi-presidential regime", Preuß prepared a complex system of checks and balances, in which the "recall procedure" of the article 43, section 2 , can be enumerate as a balance device, equilibrating the wide powers given to the President. That article established the possibility for the Reichstag to call for a "recall election" against the President. It previewed that if the electors confirm the President, the Reichstag would be considered immediately dismissed and new elections called. In addition, in this case, the President would be considered automatically re-elected for a new mandate. ${ }^{101}$ The article, however, did not specify any juridical reasons allowing the Parliament to call for a "popular recall" (Volksabstimmung). Consequently, the Reichstag would have the power to call for it for both political and juridical responsibilities of the President. The electors, instead, had no legal means to propose autonomously the recall vote against the President as collection of signatures was not allowed by the Constitution. ${ }^{102}$

Today, similar constitutional provisions are relatively widespread in Europe. The Austrian Constitution of 1920 , emended in 1929, allows a popular vote to recall the President, as well the Icelandic Constitution of 1945, the Romanian Constitution of 1991, and the Slovak Constitution of 1992, are all inspired by the first Weimar procedure. Only the Parliaments can trigger the procedures, through a majority vote (qualified or not, according to the case), the electors, instead, are not allowed collect the signatures to call the recall election against the president. The Latvian procedure is also similar. There, actually, the President has the power to pose the question at the electors whether they want to recall

99 In general, for the historical experience of the Weimar Republic see Jacobson and Schlink (2009).

100 About the form of government choosed by Preuß, see Caldwel (1997).

101 This was the text of the article: "The term of office of the Reich President lasts seven years. Re-election is permitted. The Reich President can be deposed by plebiscite, which has to be suggested by the Reichstag. This Reichstag decision requires a majority of two thirds of the votes. Such a decision bars the Reich President from continued exercise of his office. A rejection of the deposition is regarded as a re-election and results in the dissolution of the Reichstag. The Reichspräsident cannot be persecuted in a penal matter without the approval of Reichstag." (see an English translation of the Weimar constitution in McBain (1922).

102 George Burdeau identified the greater danger of this procedure in the "substantial passivity" of the electorate. See Burdeau (1932) 339. 
the Parliament, as Latvia is a unicameral system and, if they want to conserve the Parliament, the President is automatically dismissed. ${ }^{103}$

\subsection{The constitutional role of the people in the authoritative-body initiative model}

Preuß's work was partially inspired by the book of Robert Redslob Die parlamentarische Regierung in ihrer wahren und in ihrer unechten Form of $1918^{104}$ In which Redslob explained his theory about the "true" parliamentary form of Government, in which the balance between the different powers of the State has to be preserved.

According to Redslob's ideal, the President and the people should be the guardians of the balance, although in very different ways. In fact, the first organ as a permanent one has to mediate continually between the executive power and the parliament. The second organ, instead, is summoned only to solve, by the means of the general elections or the referenda, the controversies that the President failed to fix.

Starting from Redslob's thoughts, Preuß arrived at the conclusion that the electorate is not the sole owner of the sovereign power in the modern state, but it is "only" an organ like the others, like the President, Parliament and Cabinet. ${ }^{105}$ In Preuß's vision the people are not more powerful than other authoritative constitutional bodies but they are the last judges of the controversies that could happen between them. ${ }^{106}$ Moreover, Preuß was a fervent anti-socialist and an inflexible critic of Rousseau's theory of volonté générale, which he saw at the origin of the French Terror and the despotism of Robespierre. For these reasons he would never accept the idea to pose the masses of proletariat as the top of the new German Republic. ${ }^{107}$

Indeed, the people's role in founding the constitution was a main topic for all the Weimar constitutional debate. Peter Caldwell summarized that "on the one hand the people allegedly produced all state power. But on the other hand, the production of law took place only through legal procedures. Who was sovereign, the constitutional people or the democratic constitution?" 108

In many respects, the German constitutional tradition was neither progressive nor oriented towards the western liberalism with all the guaranteed rights of the individuals e.g., the Constitution of 1871 lacked of a bill of rights. Actually, the German constitutionalism was influenced by a conservative legal tradition, deeply rooted in Carl Friedrich von Gerber's thought that the individual rights did not exist in nature but only as a part of a

103 See articles 48 and 50 (Const. 1922). These articles provide a very complex mechanism through which the President can propose to the electorate the dissolution of the Sejma (the Latvian Parliament). If the people in their majority oppose the dissolution the President is considered dismissed from office. The first author to study this peculiar procedure of Latvia was the naturalized French jurist Mirkine-Guetzévitch. See Mirkine-Guetzévitch (1931) 304-20. More recently see Baldin (2012) 1-16.

104 Of this book, Robert Redslob made a second edition, in France, in 1924, in which he analysed and criticized also the Weimar constitution. The second edition was Redslob (1924). On this book see Lanchester (2009) 15.

105 See an explanation of its concept of Gebietkörperschaften (collective person) in Mezzadra (1999).

106 About Preuss's thought see Mezzadra (1999).

107 On this anti-socialist attitude of Preuss see Stirk (2002) 504.

108 Caldwel (1997) 23. 
"closed, positive legal system". ${ }^{109}$ The positive tradition, as theorized and systematized by Paul Laband ${ }^{110}$, contributed at the strengthening of the authoritarian and elitist trends settled in by the Bismarck's military politics of German unification. The strong "monarchicalprinciple based constitution of 1871 " 111 was also a way to solve the biggest problem of the famous Prussian general - How to keep together a huge set of different states (the "new" Länder) that have been historically, culturally, religiously, and politically divided?

The idea of a differentiated people and of polytheism of different values (pluralistic society) entered in the debate through Hans Kelsen's thought. For him, the people were not "a set, a mass, so to speak, but only a system of individual acts, determined by the juridical system of the state", they are "objects of power" and not "subjects". Actually, they "play a role as subject of power only when they took part at the creation of the state order". ${ }^{112}$ There is "a people" car we have a certain number of different individuals subjected to the same juridical system (the state), regardless of their feelings. There are always different interests in the people and the majority took the place of the entire electorate and, in some way, "summarize it". ${ }^{113}$ At the end, the modern democracies have to be necessarily indirect and "mediated" by the role of the parliament - it is the place of the political compromise.

Kelsen's vision states that the intervention of the political parties will be determinant. ${ }^{114}$ This was also the point of the "corporative" jurists. ${ }^{115}$ The doctrine of "state organism" (or corporatism) was started by George Jellinek and further developed by Otto von Gierke ${ }^{116}$ (who was also Preuß's mentor). This last author denied the atomistic vision of a nation composed by individuals, solemnly proclaimed by the French and American Revolutions and instead, sponsored a society (a Nation) formed by groups, as collective bodies with specific needs and beliefs. ${ }^{117}$ The political parties, churches, associations, trade unions, and also the parliament, ministers and the king, collected together give the "only" complete image of the State. The State was not something of detached by the single pieces of its body (Gebietkörperschaften) - it was each of them and none could own it. The State as a whole, made by different parties ("the people" between them), in which each part of the body has its own function.

So, what are the functions of the people? Preuß was personally persuaded of a political need for the "new" Germany; the implementation of the participation of the people in the public life. ${ }^{118}$ In educating them at political decisions and in searching to avoid a process of

109 Caldwel (1997) 46.

110 Nevertheless, in his famous speech at the University of Dresden (1896) he did not solve the question about the origin of the constitution but limited himself in describing the necessary cooperation between the king and the popular assembly.

111 On this definition see Lanchester (2008) 24.

112 More on his concept of the people see Kelsen (1929).

113 Here Kelsen was inspired by a previous work of Koigen (1912) 142. For this last Author: "The people is composed of the expression of the will of the many. When the many come together in legal, regulated relationship and administer justice, the majority of their wills becomes a people's will."

114 "The democracy exist only if the individuals collect themselves according to their political affinities, aiming to orient the general will towards their political scopes (...)." See Kelsen (1929) 63.

115 See Schmitt (2001) 87.

116 See von Gierke (1887).

117 For an organic vision of the national society see Leibholz (1933).

118 Preuß (1915). 
expulsion of the "society" from the political life of the country, Preuß wanted to preserve a people's role in the constitutional balance. ${ }^{119}$

Consequently, Preuß proposed to the Weimar National Assembly the creation of several constitutional devices for participative democracy (popular referendum and initiative). ${ }^{120}$ Article 43, section 2, of the Constitution was a clear example of this aim with the people have to decide on a conflict between the Parliament (Reichstag) and the President and having to resolve it or by dissolving the Parliament and re-electing the President, or opting for the recall of the President.

\subsection{The "plebiscitary" model and the Romania cases}

A common structure exists between the Weimar precedent and the other European procedures. The procedural structure can be summarized as follows: authoritative-body initiative (generally by the Parliament), vote, recall of the elected officer.

Clearly, the common element is that the people have to follow the initiative of a different power of the State, eventually solving a conflict between other powers. In this sense, it does not seem inapropriate to indicate them as a "plebiscitary" model. According to one definition, the plebiscite is "a vote to confirm a decision which has already been taken: in case of a yes vote, the decision is maintained; in case of a no vote, the decision should be called off and the process may be re-launched". ${ }^{121}$

Even this model can lead to abuses and this will be demonstrated by the two Romania cases (2007 and 2012) involving the president Traian Băsescu. He was twice subjected to the procedure of "presidential recall" provided by the art. 95 of the Romania Constitution of 1991. ${ }^{122}$

This last article differs from the Weimar precedent and does not require a qualified parliamentary majority i.e., two-thirds of the members, to approve the call for a recall election against the President and a simple majority is sufficient to suspend the president from his/her functions and to call for the popular vote. Moreover, Parliament is not automatically dissolved even if the people do not recall the President, and the presidential powers to dissolve the Parliament are very limited according to the Romania constitution. ${ }^{123}$ Finally, the procedure also provides an opportunity for Constitutional Court has to give its previous advice on the fairness of the accusation expressed against the President. ${ }^{124}$

119 Preuß was not the only sceptical German jurist towards the people's vote, even Hans Kelsen clearly rejected the idea of a generically rightness of the popular intervention through the referenda or plebiscites. For him the people is not "a set, a mass, so to speak, but only a system of individual acts, determined by the juridical system of the State". More on his concept of the people see Kelsen (1929).

120 A punctual analysis of the different direct democratic devices provided by the Weimar constitution in Thoma (1928) 55-73.

121 E.g., Mentan (2010) at link 11.

122 The president is elected directly by the people and many authors consider the Romania form of government as a semi-presidential one. Ex multiis, see Lime (1994) 353-77, Mcgregor (1994) 1330, and Popa (2004) 131-8. On the other hand, Vasiliescu (1995) 453 speaks about the Romania form of government as a "rationalized parliamentary" one.

123 The Romania President can only dissolve the Parliament in certain cases i.e. if the Parliament refused for two times the confidence vote to the Government (art. 89 Const.) Moreover the President can use this power only one time per year and not during the last 6 months of their mandate.

124 About the role of the Constitutional Court in Romania, see Doldur (2008), Muraru (1995) 11-32, Bartole (1996) 229-42. 
After winning the presidential election of 2004, Train Băsescu lost a large percentage of his political majority in Parliament due to a political rupture with the leader and Prime Minister of the main allied party, Călin Popescu Tăriceanu. Following the parliamentary accusation of "high violations of the constitution", the President was suspended from office by an absolute majority (322 against 108) of the Parliament in a common session (the Senate and the House of Representatives sitting together for a total of 588 members). The Constitutional Court had already stated in its advice, that the behaviour of the President could constitute "high violations of the constitutions". However, they were too vague and only politically relevant and the parliamentary accusations were only a pretext for a recall election against Băsescu in a moment of political weakness. ${ }^{125}$

The referendum was held on the 19th of May and the president was confirmed by a majority of the voters $(77,48 \%) .{ }^{126}$ Nevertheless, even if the action of Parliament, with its political majority, was widely refused by the electors, the political situation stalled as the President had no means to dissolve the Parliament. All the actors, actually, remained in charge until the end of their mandates.

The same situation occurred once more in 2012. For a second time Băsescu won the presidential elections, but lost his political majority in the two Houses of Parliament. Once more, he was accused of committing "high violations of the constitution". However, this time the Constitutional Court was even more ambiguous in its advice and the Parliament voted (256 against 114) for the suspension of the President and the call for a new popular vote, hoping to obtain a presidential recall.

The referendum took place on the 29 of July 2012, but the structural quorum for the recall election was not reached. According to Romania law, the referendum required the participation of the majority of the citizens registered in Romania. The Constitutional Court had to declare void the referendum even though the YES votes exceeded the NO. ${ }^{127}$

These Romanian precedents clearly show that the "plebiscitary model" can lead to political abuses of the recall procedure. Without appropriate legal or constitutional limitations, like as an elevate majority required (the $2 / 3$ or $3 / 5$ of the members of the Parliament) an effective and binding juridical control on the motifs for calling the recall election, it can be used as a legal instrument in a political fight against a "no more desirable" President. In this view, the abuse is simpler as the electors are only passive subjects and the parliamentary majority can choose the moment in which they "feel" there are more possibilities to obtain the recall.

\section{CONCLUSIONS}

This paper has tried to explore and explain the fundamental ideas about the popular participation trough the means of recall procedures against holders of public offices.

The first of the conclusions of this paper is that a unique recall does not exist and this expression can be used only in a very general sense, indicating all those procedures allowing the revoking of public officers through the electoral vote. In this sense, the recall is different from other revoking procedures as impeachment, confidence votes, or trials in the courts because all of them do not prescribe (in any stage of the procedure) the people's intervention.

125 On this first recall election, see the report of Baldini (2009) 63-78.

126 See the data report by the Central Electoral Office at link 12.

127 For this second case, see the complete record of Bosioc (2013) 268-75. 
Several recall procedures which are structured in very different ways, are detectable in history and current times. It has been considered that the recall proposed by the Antifederalist writers was made with the intention to use it as a political device to disempower the new Federal Congress, mainly the Senate. The progressive roots of the first Californian recall procedure of 1903 and of the others, developed in the U.S. during the first half of $20^{\text {th }}$ century has also been explored. The analyses conducted by the doctrine underlined a common structure for all these North-American procedures, based on the people's initiative and characterized by the idea of the people as the "fountainhead of the sovereignty", as summarized by Zimmerman.

It has been shown that there were possible connections between the new socialists leaders in U.S. and the European socialist writers and activists. The idea of a binding mandate for the elected representatives originated in the Rousseau's thought and found its first legal application in the Swiss Abberufungsrecht during the first years of $19^{\text {th }}$ century. The Swiss recall procedures as a direct democracy devices were incorporated into some constitutions of the German Länder and became sources of inspiration for the new socialist parties in the U.S., which evoked the imperative mandate in a political manifesto of 1897. During the same period of time, several American scholars studied the Swiss experience of direct democracy and proposed analogue models even for the U.S.

A recent application of the progressive model in the Californian case of 2003 has shown its weakness mainly a gap in the public regulation of the financial contributions for the recall campaigns allowed very rich politicians and interested privates to spent a lot of money to obtain unfairly (but legally) an easier collection of the signatures on the recall petition and a richer campaign for the recall election.

The other European plebiscitary model has also been studied which shows that there is a complete different way to understand the role of the people in these procedures; they are more passive elements than active elements. Thus, the founders of the Weimar constitution refused to recognize the people as the source of all sovereign powers because in modern democracies the supreme power has to be shared between different constitutional organs to protect the balance of the entire system. The people are only called to intervene if it is absolutely necessary - to resolve or judge hard political controversies between the other supreme powers (i.e. the President and the Parliament). So, the people cannot collect signatures on their own, calling for the recall election against the public officer, principally the President. The decision to call for a popular vote is taken autonomously by an authoritative body the Parliament or, in the Latvian case, the President.

In the progressive model, no authoritative decisions are allowed before the popular vote. There is no suspension of the public officer or other sanctions against him before the recall election. Here, the organs of the State e.g., the officers charged to control the signatures on the petition or the ones competent to call for the recall election, have no margins of political appreciation. If the legal requisites are fulfilled, they have to proceed and there cannot be any obstacles in the way of the procedure e.g., they cannot refuse to call the recall elections if there are all the mandatory requirements.

There were abuses in both cases analysed and were of a very different kind. The first case had an economical exploitation of the recall procedure in California, to avoid the legal boundaries on the financial assistance in electoral campaigns. The other case had a strong political abuse of the presidential recall in Romania by a parliamentary majority, which tried to kick out a President who twice lost his political majority in the two Houses of Parliament. Nevertheless, the unifying element in both the cases is that the political actors tried to manipulate and exploiting the legal gaps and the lacks in the constitutional 
regulation, to carry on the recall procedure at a more convenient for them. Using the economic possibilities or majority votes in the Parliament (even against the advice of the Constitutional Court), the popular vote was used as an instrument for their own purposes.

In conclusion, these manipulations show the dangerous nature of these procedures and highlight that a complete and detailed regulation always matters for a fairly development of these procedures. The progressive model implies a special attention to the phase of the initiative, in order to avoid that determined subjects can use their economic or social position to take procedural advantages. The plebiscitary model also requires juridical limitations in the initiative phase, to bound the parliamentary vote for the suspension of the President and the call for the popular vote to a larger majority or to a previous decision of an independent court.

Finally, it is capital, in order to provide useful countermeasures, to understand precisely who and how have the power to promote the procedure and to decide on its development.

\section{LITERATURE}

Aubert, J. F., 'Le referendum populaire dans la revision totale du 1872/1874' (1974) 93 Revue du droit suisse 3-16.

Baldini, S., 'I referendum arbitrali fra teoria e prassi applicative' (2012) 19 Federalismi 1-16.

Baldin, S., 'Il referendum revocatorio del Presidente della Repubblica romena: circolazione e adattamento di un singolare istituto' (2009) 1 Diritto Pubblico Comparato ed Europeo 62-80.

Barnett, J. M., The Operation of Initiative, Referendum and Recall in Oregon (Macmillan \& Co. 1915).

Bartole, S., 'Modelli di giustizia costituzionale a confronto: alcune recenti esperienze nell'Europa centro-orientale' (1996) 2 Quaderni costituzionali 229-42.

Berger, R., Impeachment. The Constitutional Problems (Harvard University Press 1973).

Bird, F.L. and Ryan, F. M., The Recall of Public Officers. Study of the Operation of the Recall in California (Macmillan \& Co. 1930).

Bognetti G., Introduzione al diritto costituzionale comparato (Giappichelli 1994).

Bosioc, D., 'Romania: la sospensione del Presidente Traian Băsescu e il referendum revocatorio del 29 luglio 2012' (2013) 2 Diritto Pubblico Comparato ed Europeo 271-88.

Bowler, S. and Cain, B., 'Introduction - Recalling the Recall: Reflections on California's Recent Political Adventure' (2004) 37 Political Science 7-10.

Böckenförde, E.W., 'Démocratie et représentation: pour une critique du débat contemporain' (2014) 16 Trivium 2-17.

Bullock, I. and Reynolds, S., 'Direct Legislation and Socialism: How British and French Socialists Viewed the Referendum in the 1890s' (1987) 24 History Workshop 62-81.

Burdeau, G., Le régime parlementaire dans les Constitutions Européennes d'après-guerre (Les éditions internationales 1932).

Caldwel, P., Popular Sovereignty and the Crisis of German Constitutional Law (Duke University Press 1997).

Cassese, S., La construction du droit administratif. France et Royaume-Uni (Montchrestien 2000).

Church, C., The Politics and Government of Switzerland (Palgrave Macmillan 2004).

Considérant, V.: La solution ou le gouvernement direct du people (Librairie Phalanstérienne 1851).

Cronin, T. E., Direct Democracy, the Politics of Initiative, Referendum and Recall (iUniverse 1989).

Crouch, W., 'Recall' Encyclopaedia Britannica 9 (1964) 10-1.

Doldur, C., 'La Cour constitutitionelle de la Romanie' in G de Vergottini (ed), Giustizia costituzionale e sviluppo democratico nei Paesi dell'Europa Centro-Orientale (Giappichelli 2008).

Dubuois, P.L. and Fleeney, F., Lawmaking by Initiative, Issues, Options and Comparisons (Agathon Press 1998).

Duguit, L., Traité de droit constitutionnel (Ancienne Librairie Fontemoigne 1923).

Elliot, J. (ed), The Debates in the Several State Conventions on the Adoption of the Federal Constitution as Recommended by the General Convention at Philadelphia in 1787 Together with 
the Journal of the Federal Convention, Luther Martin's letter, Yates's Minutes, Congressional Opinions, Virginia and Kentucky Resolutions of '98-99 and Other Illustration of the Constitution (PFE 1827).

Ensor, R. C. K., Modern Socialism, as it is Set Forth by Socialists in Their Speeches, Writings and Programmes (Harper \& brothers 1910).

Esmein, A., Élements de droit constitutionnel (Larose et Forcel 1896).

Farmer, R., 'Recall' in WB Munro (ed), The Initiative, Referendum and Recall (Appleton Company 1912).

Feeney, F., 'The 2003 California Gubernatorial Recall' (2007) 41 Creighton Law Review 37-92.

De Franciscis, C. M., 'Potere di revoca del mandato da parte del corpo elettorale in caso di disapprovazione dell'operato degli amministratori: il Recall' (2007) 6 Innovazione e Diritto $19-42$.

Garner, J. W., 'La révocation des agents publics par le peuple aux Etats Unis' (1920) 37 Revue du Droit Publique 507-21.

Garrett, E., 'Democracy In The Wake Of The California Recall' (2004) 153 University of Pennsylvania Law Review 239-84.

von Gierke, O., Die Genossenschaftstheorie und die deutsche Rechtsprechung (Weidmannsche Buchhandlung 1887).

Giraux, D., 'Les droits populaires en Suisse: vers un idéal démocratique?' (2013) 37, Siècles. Revue du centre d'histoire «espaces et cultures»1-13.

Gunlicks, A.B., 'Land Constitutions in Germany' (1998) 28 Publius 105-25.

Hamilton, M.A., 'Direct Democracy and the Protestant Ethic' (2004) 13 Journal of Contemporary Legal Issues 411-56.

Hamerow, T. S., The Age of Bismarck: Documents and Interpretations (Harper \& Row 1973).

Hazeltine, M.W., 'The Referendum and Initiative in Switzerland' (1907) 185 The North America Review 202-13.

Heath, F. F. (ed), Social Democracy Red Book (Debs Publishing Company 1900).

Henry, P., 'A Plea For the Right of Recall' in M Borden (ed), 53 The Antifederalist Papers (East Lansing 1965) 152-3.

Holligsworth, C.M., 'The So-Called Progressive Movement: Its Real Nature, Causes and Significance' (1912) 43 Annals of the American Academy of Political and Social Science 32-48.

Jacobson, A. J. and Schlink, B. (eds), Weimar. A Jurisprudence of Crisis (University of California Press 2002).

Johnson, L. J., 'Direct legislation as an ally of representative government' in WB Munro (ed), The Initiative, Referendum and Recall (Appleton Company 1912) 139-64.

Judge, D., 'Recall of MPs in the UK: "If I were You I Wouldn't Start from Here." (2012) 1 Parliamentary Affairs 732-51.

Kelsen, H., Vom Wesen und Wert der Demokratie (J.C.B. Mohr 1929).

Koigen, D., Die Kultur der Demokratie (Eugen Diederichs 1912).

Lanchester, F., Le costituzioni tedesche da Francoforte a Bonn. Introduzione e testi (Giuffré 2009).

Legrand, P., Le droit comparé (PUF 1999).

Leibholz, G., Die Repräsentation in der Demokratie (Sammlung Göschen 1973).

Leibholz, G., Die Auflösung der liberalen Demokratie in Deutschland und das autoritäre Staatsbild (Duncker \& Humblot 1933).

Lime, B., 'Le systéme constitutionnel roumaine' (1994) 2 Revue du droit public 353-77.

Mack, E. E., 'The Use and Abuse of Recall: A Proposal for Legislative Recall Reform' (1988) 67 Nebraska Law Review 617-40.

Mai, G., Die Weimarer Republik (C.H. Beck 2009).

McBain, H.L., Roger, L., The New Constitutions of Europe (Doubleday 1922).

Mcgregor, J.P., 'Qui gouverne? Partis, Parlements, Cabinets, cours constitutionelles et Président en Europe centrale et orientale post-communistes' in E. Lhomel and T. Schreiber (eds.), L'Europe centrale et orientale (Les études de La Documentation française 1994) 13-30.

Mezzadra, S., La costituzione del sociale, Il pensiero politico e giuridico di Hugo Preuss (Il Mulino 1999). 
Miller, K. P., 'The Davis Recall and the Courts' (2005) 30 American politics research 135-62.

Mirkine-Guetzévitch, B., 'Le referendum et le régime parlamentaire' (1931) 1 Revue politique et parlamentaire 304-20.

Monateri, P. G., 'Methods in Comparative Law: an Intellectual Overview' in PG Monateri (ed), Methods of Comparative Law (Edward Elgar 2012) 7-24.

Munro, W. B., 'Introduction' in WB Munro (ed), The Initiative, Referendum and Recall (Appleton Company 1912) 1-51.

Muraru, I., Constantinescu and M., 'La juridiction constitutionnelle en Roumanie' (2013) 29 Annuaire international de Justice constitutionnelle 11-32.

Olivetti, M., 'Il recall e i nuovi statuti regionali' in A. Barbera (ed), La potestà statutaria regionale nella riforma della Costituzione (Giuffré 2001) 355-78.

Oliviero, M., Impeachment. Dalle origini inglesi all'esperienza degli Stati Uniti d'America (Giappichelli 2001).

Parson, F., The City for the People or the Municipalisation of the City Government and of Local Franchises (C.F. Taylor 1901).

Persily, N. A., 'The Peculiar Geography of Direct Democracy: Why the Initiative, Referendum and Recall Developed in the American West' (1997) 2 Michigan Law \& Policy Review 11-41.

Phelps, E. M., 'Introduction' in M Phelps (ed), Selected Articles on the Recall Including the Recall of Judges and Judicial Decisions (H.W. Wilson Company 1915) 1-5.

Pitkin, H., The Concept of Representation (University of California Press 1967).

Plotke, D., 'Representation is Democracy' (1997) 4 Constellations 19-34.

Popa, N., 'La révision de la Constitution roumaine' (2004) 2 Revue de Justice constitutionelle esteuropéenne 131-8.

Preuß, H., Das deutcshe Volk und die Politik (Humboldt 1915).

Rappart, W.E., 'The Initiative, Referendum and Recall in Switzerland' (1912) 43 Annals of the American Academy of Political and Social Science 110-45.

Redslob, R., Le Régime parlementaire: étude sur les institutions d'Angleterre, de Belgique, de Hongrie, de Suède, de France, De Tchécoslovaquie, de l'Empire allemand, de Prusse, de Bavière et d'Autriche (M. Giard 1924).

Rittinghausen, M., La legislation directe par le people (Librairie Phalanstérienne 1851).

Ronchi, P., 'Una forma di democrazia diretta: l'esperienza del recall negli Stati Uniti d'America' (2009) 61 Quaderni dell'Osservatorio Elettorale 99-129.

Sacco, R., 'Legal Formants: a Dynamic Approach to Comparative Law' (1991) 39 The American Journal of Comparative Law 1-35 and 341-401.

Schmitt, C. and Hugo Preuß. 'Il suo concetto di Stato e la sua posizione nella dottrina tedesca dello Stato' in C Schmitt (ed), Democrazia e liberalismo (Giuffré 2001).

Shaffner, M. A., 'Recall' in M Phelps (ed), Selected Articles on the Recall Including the Recall of Judges and Judicial Decisions (H.W. Wilson Company 1915).

Sieyès, J. E., Qu'est-ce que le Tiers état? (Societé de l'Histoire de la Revolution Française 1888).

Sitton, T., 'California's Practical Idealist: John Randolph Haynes' (1988) 57 California History $2-17$.

Stagner, S., 'The Recall of Judicial Decisions and the Due Process Debate' (1980) 24 The American Journal of Legal History 257-72.

Stirk, P., 'Hugo Preuss, German Political Thought and the Weimar Constitution' (2002) 13 History of political thought $497-516$.

Storing, H. J. (ed), The complete Antifederalist (University of Chicago Press 1981).

Sullivan, J.W., Direct Legislation by the Citizenship (Twentieth Century Publishing Company 1892).

Tatah-Mentan, I., 'Stopping War before it Starts: Testing Preventive Diplomacy in the Selfdetermination Case of British Southern Cameroons (aka Ambazonia)' in F. Achankeng (ed), British Southern Cameroons: Nationalism \& Conflict in Postcolonial Africa (FriesenPress 2014) 127-70.

Thoma, R., 'The Referendum in Germany' (1928) 10 Journal of Comparative Legislation and International Law 55-73.

Testi, A., Il socialismo americano nell'età progressista (Marsilio 1980). 
Urbinati, N., Representative Democracy. Principles and Genealogy (University of Chicago Press 2006).

Vasiliescu, F., 'Considération sur le régime politique actuel de la Roumanie' (1995) 23 Revue française de droit constitutionnel 451-81.

Watson, A., Legal Transplants. An Approach To Comparative Law (University of Georgia Press 1993).

Wells, R. H., 'The Initiative, Referendum, and Recall in German Cities' (1929) 18 National Municipal Review 29-36.

Wilcox, D. F., Government by All the People, or the Initiative, Referendum and the Recall as Instruments of Democracy (Macmillan Company 1912).

Zick, T., 'The Consent of the Governed: Recall of United States Senators' (1999) 103 Dickinson Law Review 572-611.

Zimmerman, J. F., The Recall. Tribunal of the People (State University of New York Press 2013).

\section{LINKS}

1. http://www.legislation.gov.uk/ukpga/2015/25/contents/enacted (last access on 5 March 2016).

2. http://zum.de/psm/weimar/weimar_vve.php (last access on 5 March 2016).

3. https://www.ourdocuments.gov/doc.php?doc=3\&page=transcript (last access on 5 March 2016).

4. https://www.congress.gov/resources/display/content/The+Federalist+Papers (last access on 5 March 2016).

5. https://catalog.hathitrust.org/Record/011716478) (last access on 5 March 2016).

6. http://www.idea.int/publications/direct_democracy (last access on 9 March 2016).

7. http://dx.doi.org/10.1080/00344893.2015.1056219 (last access on 9 March 2016).

8. https://siecles.revue.org/214 (last access on 5 March 2016).

9. http://www.commune1871.org/?La-Commune-de-Paris (last access on 10 march 2016).

10. www.marxists.org (last access 30 march 2016).

11. www.postwatchmagazine.com (last access on 5 March 2016).

12. http://www.becreferendum2007.ro/document3/rez\%20finale.pdf (last access on 5 March 2016). 